\section{Homeopathy and Periodontal Treatment in Type II Diabetic Patients: a 1-Year Randomized Clinical Trial}

\author{
Leila Mourão ${ }^{1}$, Romeu Carillo $\mathrm{Jr}^{2}$, Sabrina Martins Linares ${ }^{3}$, Antonio
} Canabarro $^{1,4}$, Ricardo Guimarães Fischer ${ }^{4}$

\author{
'Department of Periodontology, \\ School of Dentistry, UVA - \\ Universidade Veiga de Almeida \\ Rio de Janeiro, RJ, Brazil \\ ${ }^{2}$ Department of Homeopathy, \\ UNICID - Universidade Cidade de \\ São Paulo, São Paulo, SP, Brazil \\ ${ }^{3}$ Departament of Periodontology, \\ IEDE - Instituto Estadual de \\ Diabetes e Endocrinologia, \\ Rio de Janeiro, RJ, Brazil \\ ${ }^{4}$ Departament of Periodontology, \\ UERJ - Universidade do Estado do Rio \\ de Janeiro, Rio de Janeiro, RJ, Brazil \\ Correspondence: Ricardo Guimarães \\ Fischer, Boulevard 28 de Setembro, \\ 157, $2^{\circ}$ Andar, 20551-030 Rio de \\ Janeiro, RJ, Brasil. Tel: +55-21-2334- \\ 2076. e-mail: ricfischer@globo.com
}

Key Words: chronic periodontitis, periodontal therapy homeopathy, diabetes mellitus.

\section{Introduction}

Chronic periodontitis (CP) is a destructive inflammatory disease of the supporting tissues of the teeth that results from the disruption of homeostasis between subgingival microbiota and host defenses (1). The inflammation of the periodontal tissues results in periodontal pocket formation and bone loss. Epidemiologic studies showed that 10\% to $15 \%$ of the adult population may have a severe form of CP (2). In its most advanced stage, CP leads to teeth loss, reducing quality of life and impacting general health.

Diabetes Mellitus (DM) is defined as a metabolic disorder of multifactorial etiology, characterized by chronic hyperglycemia with disturbances in the metabolism of carbohydrates, lipids and proteins, resulting from defects in insulin secretion, or its action (3). It is estimated that 346 million people have diabetes worldwide with the prediction of 439 million by the year 2030, representing an increase of $54 \%$ in 20 years to encompass almost one tenth of adults 20 years and older (4).

Periodontal disease may be linked to metabolic and systemic control in a bidirectional way, and may hinder the glycemic control of diabetes, related to the acute interference of the absorption of insulin, leading to chronic hyperglycemia (5). Several studies pointed out that the existence of the dental biofilm in the diabetic patient may cause a more severe gingivitis as compared to gingivitis in non-diabetic patients. Patients with impaired glucose level may have more severe periodontitis (6). On the other hand, diabetic patients with severe periodontitis may have higher difficulty to achieve a proper glycemic control (7).

Homeopathy may restore the balance of the vital energy of the patient allowing the healing movement of the body (8). It is a therapeutic system based on the principle of similarity, uses medicines from all the kingdoms of nature (mineral, vegetable and animal), and is administered to healthy people to produce the same symptoms of the disease that is under treatment $(7,8)$. Clinical experience suggests that it is effective, relatively inexpensive and has high patient satisfaction and a low incidence of side effects (9). In fact, homeopathy drugs, as an adjunctive to conventional periodontal treatment, may provide significant local and systemic improvements for $\mathrm{CP}$ patients (8). Also, they may prevent diabetes complications by inhibiting albumin glycation of erythrocytes in vitro (10), and improve insulin action through activation of insulin signaling molecules in skeletal muscle of type-2 diabetic rats (11). However, despite important growth in homeopathy research (12), highquality clinical research is needed to allow a more decisive interpretation of the role of homeopathy in the treatment of diabetic patients. The hypothesis of the study is that Homeopathy may benefit treatment outcomes as adjunct of non-surgical periodontal therapy. Therefore, the aim of this 
randomized 1-year study was to evaluate the clinical and laboratorial longitudinal effects of homeopathic therapy as adjunct to the non-surgical periodontal treatment (NSPT) of generalized chronic periodontitis (CP) in patients with diabetes mellitus type 2 (DMII) and CP.

\section{Material and Methods}

One hundred individuals of both genders aged between 32 and 70 years in diabetes treatment in the State Institute of Diabetes and Endocrinology (IEDE)-RJ/Brazil were invited to participate in this study between March 01, 2013 and November 30,2013. The patients should have a diagnosis of DMII attested by an endocrinologist and present generalized chronic periodontitis (CP). Severe chronic periodontitis was defined if the patient presented at least 2 proximal sites of 2 non adjacent teeth with probing pocket depth $(\mathrm{PPD}) \geq 6 \mathrm{~mm}$ and clinical attachment loss $(\mathrm{CAL}) \geq 5 \mathrm{~mm}$ (13). The exclusion criteria were: (a) patients that received periodontal treatment 12 months prior to the beginning of the study, (b) patients with Aggressive Periodontitis, (c) smokers, (d) pregnant women, (e) patients with medical conditions that might affect the periodontal tissues and the degree of healing, such as HIV, and ( $f$ ) patients that $\dot{s}$ used medications such as anti-inflammatories or antibiotics in the previous 6 months. The study was reviewed and approved by the Ethic and Research Committee (CEP) of Veiga of Almeida University (UVA), RJ/Brazil (CEP/UVA protocol number 285-11).

The evaluation of the medical and dental history of the patients was carried out by an examiner (LM) through an individual questionnaire to identify possible risk factors. The information recorded included gender, age, systolic and diastolic blood pressure, presence of heart disease, family history of diabetes, use of medications, dyslipidemia, measurement of waist circumference, body mass index (BMI) and lifestyle.

\section{Allocation and Randomization}

Eighty patients with $\mathrm{CP}$ and DMII were randomly distributed after a computer generated table (SAS Software Version 8.2 for Windows) into 2 groups, test and control (allocation ratio 1:1). The randomization table was sent to a pharmacy, where a pharmaceutical prepared the placebo and homeopathic formulas, and coded them. These codes were broken after the collection and analysis of the statistical data. The list of patients and their respective test/control treatment codes were sent to a participant (AC), which distributed the medications. Both the assessing periodontist (LM) and the patients were blind to group allocation.

\section{Clinical Parameters}

All patients underwent a complete periodontal examination by a blinded periodontist (LM), using a manual periodontal probe (PCPUNC, Hu-Friedy, Chicago, IL, USA). Periodontal examinations included measurements of probing pocket depth (PPD), clinical attachment loss (CAL), visible plaque index (VPI) and bleeding on probing (BOP). All parameters were measured in 6 sites (mesiobuccal, buccal, diatobuccal, mesiopalatal or mesiolingual, lingual or palatal and disto-lingual or disto-palatal), except third molars.

\section{Examiner Calibration}

Examiner calibration was performed during a pilot study that preceded the present investigation. CAL, PPD, BOP and VPI were carried out by one examiner at different times. Six sites of all present teeth from 8 patients with $\mathrm{CP}$ were examined twice, with a week interval. The InterClass Correlation Coefficient (ICC) was $0.82(p=0.57), 0.84$ $(p=0.79), 0.99(p=0.93)$ and $0.97(p=0.92)$ for $C A L, P D, B O P$ and VPI, respectively.

\section{Treatment Protocols}

All CP patients $(n=80)$ received nonsurgical periodontal treatment (NSPT). The therapy included oral hygiene instructions, a brief description of periodontitis and its local and systemic effects, supragingival scaling, subgingival scaling and root planning, performed with Gracey currettes (Hu-Friedy, Chicaco, IL, USA) and ultrasonic scaler tips (Profi Neo, Dabi Atlante, Ribeirão Preto, SP, Brasil). The number of visits was limited to four. If there was no tooth in a given quadrant, the number of visits was reduced to the number of quadrants present. The mean instrumentation time was 10 min per tooth.

\section{Test Group (TG) - Additional Homeopathic Therapy}

Forty patients received an additional homeopathic therapy (TG). The medications were selected according to the similar principle, and include a depurative medicine, Berberis 6CH (two tablets, 2x/daily, 45 days), an acute drug Mercurius solubilis / Belladona / Hepar sulphur - 6CH (two tablets, 3x/daily, 15 days) and a bioterapic Pyrogenium - $200 \mathrm{CH}$, (single weekly dose, 2 weeks). Depurative medicine presents an elective action on the tissue or organ malfunction which prevents elimination of substances produced or introduced into the body. Acute drugs are prescribed in low concentrations in order to cover all signs and symptoms of local lesions, while bioterapic drug is used for chronic stimulation of the individual's energy (14).

\section{Control Group (CG) - Placebo}

Forty patients in the control group received placebo medications, which followed the same dosage in its structural form. 


\section{Blood Examinations}

All patients underwent blood tests performed in the laboratory of IEDE, collected at baseline, 6 and 12 months after NSPT. The lipid profile was measured by standardized colorimetric methods. Values of cholesterol and triglycerides were obtained by enzymatic colorimetric methods (Automation, Modular Roche Diagnostics AG, Mannheim, Germany). Plasma glucose $(\mathrm{mg} / \mathrm{dL})$ was determined by the method GOD-PAD Automation (Roche). The uric acid was measured by colorimetric kit 80 Pap (ABX Diagnostic-SP, Montpellier, France). For Glycated hemoglobin, the used method was certified by the National Standardization Program-Gllycohemoblobin (USA).

\section{Primary and Secondary Outcomes}

CAL was defined as primary outcome. PPD, VPI, BOP and blood examinations were secondary outcomes.

\section{Statistical Analysis and Sample Size Calculation}

The sample size was calculated to promote a $90 \%$ power and alpha value of $5 \%$ to detect significant differences in the mean levels of the primary outcome (CAL) between the two groups. For a mean CAL of $5.4 \mathrm{~mm}$ and considering an expected reduction of $10 \%$, and standard deviation of
$0,7 \mathrm{~mm}$, it would be necessary 35 patients in each group. To compensate for drop-outs, a 10\% increase in the size of the sample was carried out. Statistical analysis was performed using the SPSS version 21.0 for Windows (SPSS Inc., Chicago, IL, USA). Initially, the normality of the data was checked with the Kolmogorov-Smirnov test. If the data was normally distributed, parametric tests were used. Kruskal Wallis test was used to compare values between test and control groups, while Friedman test was used to for intra-group analysis. For all analyses the statistical significance level was established at 5\%.

\section{Results}

In total, 80 patients were selected for the study. All patients met for all observation visits and completed the one-year study (Fig. 1).

At baseline, age, gender and race distributions, BMI and waist circumference were equivalent in both groups. There was no statistically significant difference between the test and control groups in relation to the demographic and periodontal characteristics (Table 1).

All clinical parameters were similar in the test and control groups on baseline (Table 2).

Periodontal treatment resulted in significant

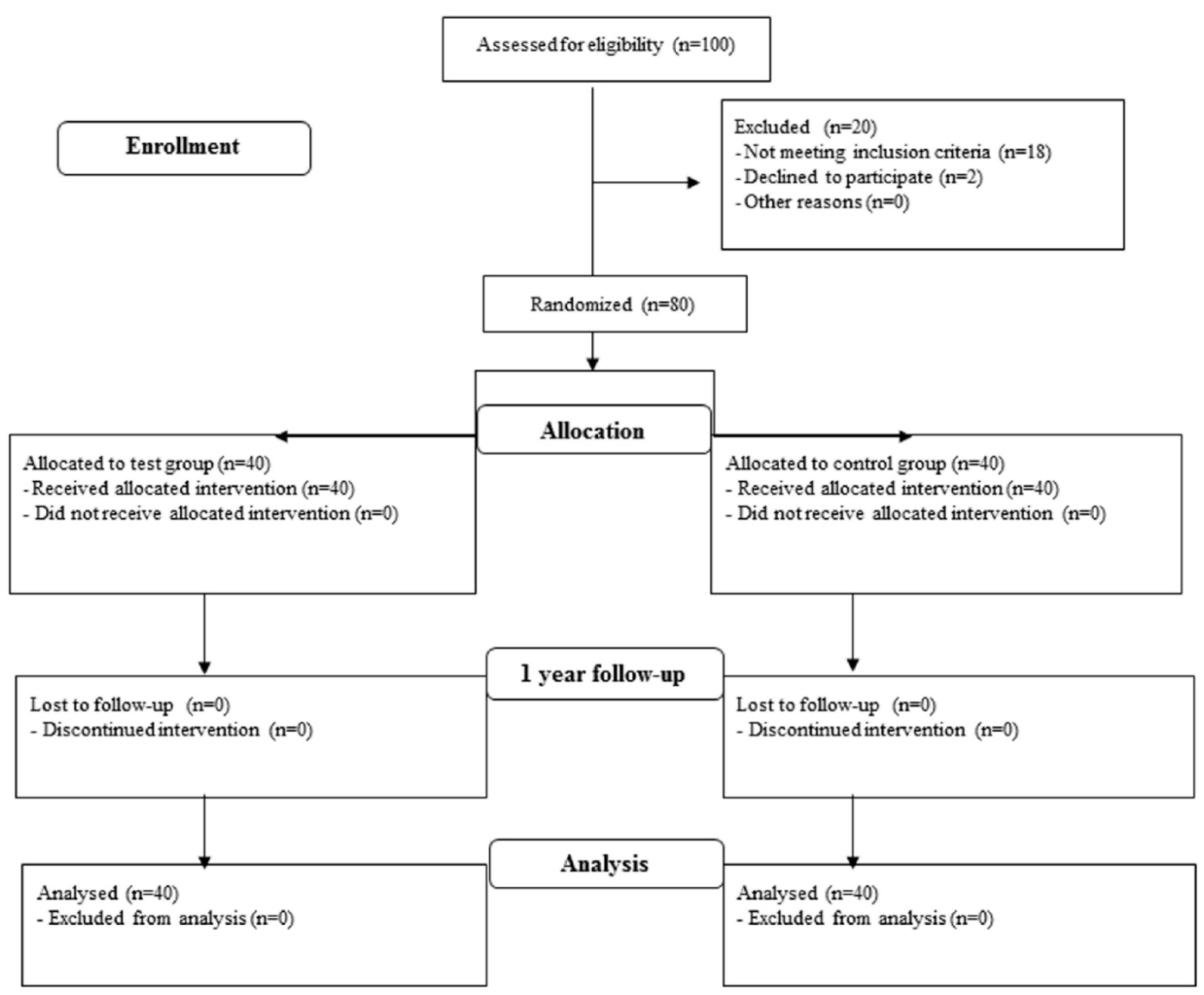

Figure 1. Participants flow chart. 
improvement of VPI, BOP, CAL and PPD in both groups (Table 2). A significant reduction of VPI was observed in both groups after 6 months of observation with statistical differences between test and control groups after $(1,6)$ and 12 months. After 12 months, VPI values of the test patients remained below baseline value (Table 2). BOP significantly decreased after 1 month of periodontal treatment, and remained low after 12 months in both test and control groups. There was no significant difference between groups during the period of observation (Table 2). A significantly gain of CAL was observed after 1 month of periodontal treatment and during the 12 months of observation, in both test and control group. However, a statistically significant difference in mean CAL between test and control patients was noted. TG presented significative gain of CAL at 1 and 12 months compared to CG. The mean \% of sites with $C A L \leq 3 \mathrm{~mm}$ was higher in $\mathrm{TG}$ than in $\mathrm{CG}$ at 6 and 12 months. Such difference between test and control patients was also observed in sites with 4-5 mm of CAL at 6 month (Table 2). Mean values of PPD significantly reduced after 1 month of periodontal treatment in both groups but remained below baseline values during the 12 months of observation only in TG. Comparing both groups, it was observed a significative PPD reduction in TG at 30 days of observation (Table 2).

In the TG, the mean levels of total cholesterol (TC), LDL and triglyceride decreased significantly 6 months after periodontal treatment and remained low after 12 months. The mean HDL levels increased significantly 6 months after periodontal treatment. In the $\mathrm{CG}$, there was no significant change in lipid profile. Periodontal treatment significantly decreased blood glucose values, glycated hemoglobin and uric acid 6 months and 12 months after periodontal treatment. In the TG, there was a significant decrease in these values when compared to those observed in the

Table 1. Comparison between the control group (CG) and test group (TG) at baseline regarding the demographic and periodontal characteristics

\begin{tabular}{lcc}
\hline & CG $(\mathrm{n}=40)$ & TG $(\mathrm{n}=40)$ \\
\hline Age & $49.6( \pm 8.5)$ & $49.4( \pm 8.6)$ \\
Gender (Male / Female) & $17 / 23$ & $19 / 21$ \\
Race (white) (\%) & 46 & 37 \\
Number of teeth & $23.6( \pm 4.2)$ & $24.5( \pm 4.2)$ \\
Body mass index & $31.4( \pm 5.9)$ & $31.7( \pm 5.6)$ \\
Abdominal circumference (cm) & $91( \pm 22.7)$ & $103.4(11.7)$ \\
Bleeding on probing $(\%)$ & $52( \pm 13)$ & $53( \pm 13)$ \\
Visible plaque index (\%) & $77( \pm 8)$ & $74( \pm 9)$ \\
Clinical attachment level (mm) & $5.2( \pm 0.5)$ & $5.4( \pm 0.7)$ \\
Probing pocket depth (mm) & $5.1( \pm 0.5)$ & $5.4( \pm 0.4)$ \\
Severe chronic periodontitis $(\%)$ & 47.5 & 50 \\
\hline
\end{tabular}

Table 2. Mean $( \pm$ SD) of the clinical parameters of the test group (TG) and the control group (CG) at baseline, 1 month, 6 months and 12 months

\begin{tabular}{|c|c|c|c|c|}
\hline $\begin{array}{l}\text { Clinical } \\
\text { parameters }\end{array}$ & Time & CG $(n=40)$ & TG $(n=40)$ & $\begin{array}{c}\text { Intergroup } \\
p \text { value }\end{array}$ \\
\hline \multirow{4}{*}{ VPI (\%) } & Baseline & $77.4(7.8)$ a & $74.4(9.5) \mathrm{A}$ & ns \\
\hline & $1 \mathrm{~m}$ & $62.6(13.6) \mathrm{b}$ & 39.5 (7.7) B & $<0.001^{*}$ \\
\hline & $6 \mathrm{~ms}$ & $46.7(8.8) \mathrm{c}$ & $31.4(8.3) \mathrm{C}$ & $<0.001^{*}$ \\
\hline & $12 \mathrm{~ms}$ & $78.2(8.3) \mathrm{a}$ & $50.8(21.4) \mathrm{D}$ & $<0.001^{*}$ \\
\hline \multirow{4}{*}{ BOP (\%) } & Baseline & $52.2(13.1) \mathrm{a}$ & 53.8 (13.3) A & ns \\
\hline & $1 \mathrm{~m}$ & $25.7(8.0) \mathrm{b}$ & 26.2 (9.3) B & ns \\
\hline & $6 \mathrm{~ms}$ & $10.3(6.2) c$ & $11(6.2) \mathrm{C}$ & ns \\
\hline & $12 \mathrm{~ms}$ & $10.6(5.5) \mathrm{c}$ & 11.7 (6.1) C & ns \\
\hline \multirow{4}{*}{ CAL (mm) } & Baseline & $5.2(0.5)$ a & $5.4(0.7) \mathrm{A}$ & ns \\
\hline & $1 \mathrm{~m}$ & $4.4(0.3) \mathrm{b}$ & $4.3(0.2) \mathrm{B}$ & $0.04^{*}$ \\
\hline & $6 \mathrm{~ms}$ & $4.5(0.3) \mathrm{b}$ & $4.4(0.3) \mathrm{B}$ & ns \\
\hline & $12 \mathrm{~ms}$ & $4.5(0.4) \mathrm{b}$ & $4.5(0.3) \mathrm{B}$ & $0.03^{*}$ \\
\hline \multirow{4}{*}{$\begin{array}{l}\text { CAL (\%) } \\
4-5 \mathrm{~mm}\end{array}$} & Baseline & $63.5(18.5) \mathrm{a}$ & $68(15.8) \mathrm{A}$ & ns \\
\hline & $1 \mathrm{~m}$ & 73 (14.8) b & 80.5 (18.5) B & $0.04^{*}$ \\
\hline & $6 \mathrm{~ms}$ & $76(16.8) b$ & 73 (17.5) A & $0.008^{*}$ \\
\hline & $12 \mathrm{~ms}$ & $81(16.3) \mathrm{b}$ & $78(14.5) \mathrm{B}$ & ns \\
\hline \multirow{4}{*}{$\begin{array}{l}\text { CAL }(\%) \\
\geq 6 \mathrm{~mm}\end{array}$} & Baseline & $31(22)$ a & $28.5(24.5) \mathrm{A}$ & Ns \\
\hline & $1 \mathrm{~m}$ & $8(13.8) \mathrm{b}$ & $3(10.8) \mathrm{B}$ & $0.02^{*}$ \\
\hline & $6 \mathrm{~ms}$ & $11(12.8) \mathrm{b}$ & 15 (17.5) C & $0.04^{*}$ \\
\hline & $12 \mathrm{~ms}$ & $11(12.8) \mathrm{b}$ & 8 (13.5) C & ns \\
\hline \multirow{4}{*}{ PPD (mm) } & Baseline & $4.8(0.3) \mathrm{a}$ & $4.9(0.3) \mathrm{A}$ & ns \\
\hline & $1 \mathrm{~m}$ & $4.7(0.3) \mathrm{b}$ & $4.5(0.2) \mathrm{B}$ & ns \\
\hline & $6 \mathrm{~ms}$ & $4.8(0.3) \mathrm{a}$ & $4.7(0.3) \mathrm{C}$ & ns \\
\hline & $12 \mathrm{~ms}$ & $4.8(0.3) \mathrm{a}$ & $4.8(0.3) \mathrm{C}$ & ns \\
\hline \multirow{4}{*}{$\begin{array}{l}\text { PPD (\%) } \\
4-5 \mathrm{~mm}\end{array}$} & Baseline & $62.6(19) \mathrm{a}$ & 65.4 (23.3) A & ns \\
\hline & $1 \mathrm{~m}$ & $71.3(23.2) \mathrm{a}$ & 74.1 (16.5) A & ns \\
\hline & $6 \mathrm{~ms}$ & 73.7 (19.7) b & 73.4 (12.9) A & ns \\
\hline & $12 \mathrm{~ms}$ & 78.8 (14.6) b & 75.6 (18.2) A & ns \\
\hline \multirow{4}{*}{$\begin{array}{l}\text { PPD }(\%) \\
\geq 6 \mathrm{~mm}\end{array}$} & Baseline & $30.9(21.7) \mathrm{a}$ & 29.7 (22.5) A & ns \\
\hline & $1 \mathrm{~m}$ & $8.3(12) b$ & $4.2(9.1) \mathrm{B}$ & $0.05^{*}$ \\
\hline & $6 \mathrm{~ms}$ & $9.8(13.2) \mathrm{b}$ & $9.2(10.2) \mathrm{B}$ & ns \\
\hline & $12 \mathrm{~ms}$ & 13 (11.9) b & 8 (11.6) B & ns \\
\hline
\end{tabular}

VPI - visible plaque index; BOP - bleeding on probing; $\mathrm{CAL}$ - clinical attachment loss; PPD - probing pocket depth. Intergroup analyses: * statistical sugnificance. Intragroup analyses: TG- capital letters, CGsmall letters. Different letters means statistical significance $(p<0.05)$. 
Table 3. Median (interquartil interval) of the serological tests of the test group (TG) and control group (CG) at baseline, 6 months and 1 year.

\begin{tabular}{|c|c|c|c|c|}
\hline Parameters & time & CG $(n=40)$ & TG $(n=40)$ & $\begin{array}{c}\text { Intergroup } \\
\mathrm{p} \text { value }\end{array}$ \\
\hline \multirow{5}{*}{$\begin{array}{l}\text { LDL } \\
(\mathrm{mg} / \mathrm{dl})\end{array}$} & Baseline & $145(67.7)$ & $141(82.4)$ & ns \\
\hline & 6 months & $126.7(52.3)$ & $124.5(52.5)$ & ns \\
\hline & 12 months & $134.5(56.8)$ & $115.2(42)$ & \multirow[t]{2}{*}{$0.03^{*}$} \\
\hline & $\mathrm{p}$ value & 0.000 & 0.000 & \\
\hline & Baseline & $51(16)$ & $43.5(10.8)$ & ns \\
\hline \multirow{4}{*}{$\begin{array}{l}\mathrm{HDL} \\
(\mathrm{mg} / \mathrm{dl})\end{array}$} & 6 months & 48.5 (15) & $51(12)$ & ns \\
\hline & 12 months & $47(12)$ & $49.5(9)$ & \multirow[t]{2}{*}{ ns } \\
\hline & $p$ value & 0.03 & 0.000 & \\
\hline & Baseline & $219(57.8)$ & $189(57.3)$ & ns \\
\hline \multirow{4}{*}{$\begin{array}{l}\text { Total } \\
\text { col (mg/ } \\
\text { dl) }\end{array}$} & 6 months & $198(39.3)$ & $166.5(45.5)$ & $0.000^{*}$ \\
\hline & 12 months & $210(42)$ & $175.5(56)$ & \multirow[t]{2}{*}{$0.001^{*}$} \\
\hline & $\mathrm{p}$ value & NS & NS & \\
\hline & Baseline & $143(74)$ & $154.5(109.5)$ & ns \\
\hline \multirow{4}{*}{$\begin{array}{l}\text { Trig } \\
(\mathrm{mg} / \mathrm{dl})\end{array}$} & 6 months & $137(66.3)$ & 113 (85) & ns \\
\hline & 12 months & $137(80.3)$ & $112(84.8)$ & \multirow[t]{2}{*}{ ns } \\
\hline & $\mathrm{p}$ value & 0.000 & 0.000 & \\
\hline & Baseline & 118 (59) & $118(14.8)$ & ns \\
\hline \multirow{4}{*}{$\begin{array}{l}\text { Gli (mg/ } \\
\text { dl) }\end{array}$} & 6 months & $98(15)$ & $90.5(7.5)$ & $0.000^{*}$ \\
\hline & 12 months & $107.5(11)$ & $93.5(10)$ & \multirow[t]{2}{*}{$0.000^{*}$} \\
\hline & $\mathrm{p}$ value & 0.000 & 0.000 & \\
\hline & Baseline & $7.2(1.6)$ & $7.5(1.3)$ & ns \\
\hline \multirow{4}{*}{$\begin{array}{l}\mathrm{HbA} 1 \mathrm{c} \\
(\%)\end{array}$} & 6 months & $6.2(1.9)$ & $5.6(1.9)$ & $0.001^{*}$ \\
\hline & 12 months & $6.6(1.8)$ & $5.8(1.2)$ & \multirow[t]{2}{*}{$0.000^{*}$} \\
\hline & $\mathrm{p}$ value & 0.000 & 0.000 & \\
\hline & Baseline & $6.5(2.7)$ & $6.8(1.3)$ & ns \\
\hline \multirow{4}{*}{$\begin{array}{l}\text { Uric } \\
(\mathrm{mg} / \mathrm{dl})\end{array}$} & 6 months & $5.9(1.8)$ & $4.8(1)$ & $0.005^{*}$ \\
\hline & 12 months & $6.1(2.1)$ & $4.8(1.2)$ & \multirow[t]{2}{*}{$0.001^{*}$} \\
\hline & $\mathrm{p}$ value & 0.000 & 0.000 & \\
\hline & Baseline & $1.8(0.4)$ & $2.1(0.9)$ & $0.05^{*}$ \\
\hline \multirow{3}{*}{$\begin{array}{l}\text { CRP } \\
(\mathrm{mg} / \mathrm{dl})\end{array}$} & 6 months & $1.2(0.5)$ & $1.1(0.4)$ & ns \\
\hline & 12 months & $1.3(0.4)$ & $1.3(0.3)$ & \multirow[t]{2}{*}{ ns } \\
\hline & $\mathrm{p}$ value & 0.000 & 0.000 & \\
\hline
\end{tabular}

LDL: LDL Cholesterol; HDL: HDL cholesterol; Total col: total cholesterol; Trig: Triglycerides; Gli: blood glucose; HbA1c: glycated Hemoglobin; Uric uric acid; CPR: C-reactive protein.
CG, at 6 and 12 months. The mean CRP levels decreased significantly after periodontal treatment in both groups, however no statistical difference was observed between the TG and CG (Table 3).

\section{Discussion}

The aim of this study was to evaluate longitudinally (1 year) the additional effect of homeopathic drugs associated with NSPT to improve periodontal and laboratorial parameters in patients with $\mathrm{CP}$ and DMII. The results showed improved clinical and systemic conditions in the test and control groups. However, there was a significantly further reduction of VPI, CAL, Total cholesterol, glucose, HbA1c and acid uric in the TG, as compared to CG 12 months after treatment.

Periodontal clinical parameters showed a significant improvement after periodontal treatment in both groups, indicating that NSPT was effective and in line with other clinical studies (15-17). Mean values of VPI significantly reduced in both groups, however the values observed in the test group were significantly lower than those observed in the control group. An eventual effect of Homeopathy on this further reduction is most unlikely to occur. Moreover, the significance of these further reductions of VPI in the test group may be not clinically significant, since the mean values of BOP, PPD and CAL presented similar reductions in both groups. Individuals with periodontal disease and DMII showed similarities on PPD and CAL mean values. However, TG presented significative gain of CAL at 1 and 12 months compared to $C G$ and a more evidente reduction in PPD when homeopathy was used, showing that in type 1 diabetics the use of an adjunct drug, associated to NSPT may provided more significant inflammatory reduction (15). Intergroup analysis showed similar levels of bleeding at baseline in 30 days, 6 and 12 months.

The glucose and glycated hemoglobin decreased in both groups, which is consistent with studies showing a beneficial effect of periodontal treatment on glycemic control in diabetic patients (18). The effects were demonstrated after 3 months, and remained low after 6 and 12 months. The cell impairment in diabetes is intense due to this oxidative stress, resulting in the activation of compensatory mechanisms that induce $\beta$ cells to secrete more insulin (19). In the test group, the decrease of these parameters was more significant at 6 and 12 months. The use of NSPT associated with homeopathic therapy may have contributed to further reduction in TG patients. The complex homeopathic used, including Merc sol, Bell, Hepar sulph, may have acted on the reduction of cellular oxidative stress and, especially, in the reduction of TNFa, regulating thereby the stimulation of immune activity (8).

Cell hypoxia promotes cell dysfunction depending on 
the number of cells involved that may compromise organ function (7). This functional failure in the long term may contribute to the development of a chronic disease. In diabetes, the hypoxia causes cell disruption and reduced secretion of insulin by pancreas and liver glycogenolysis processes decreasing glucose blood levels (20). Berberis drug is an alkaloid is berberine and hepatorenal renal function, which operates drainer glycogenolysis, providing the activation of Langerhans cells (14). It is a drug acting in the extracellular matrix, and may promote cell autoregulation, through the activation of the functions of its cellular receptors. The action of this drug may have contributed to the decrease in glucose and glycated hemoglobin (21).

Uric acid is the final product of purine metabolism, generated after breaking of DNA, RNA, ATP and proteins, and may serve as a connective and vascular damage mediator (22). Elevated uric acid concentrations favor the development of kidney problems and increase the chances of development of obesity, metabolic syndrome, diabetes, fatty liver, arterial hypertension and cardiovascular disease (22). It may also stimulate the production of CRP, known to be a predictive marker of progression of atherosclerotic cardiovascular disease (23). The elevated uric acid may $\therefore$ promote endogenous aggression in canaliculi and hepatic joint capsules, and especially the collagen coating the periodontium. The DMII is associated with increased oxidative stress. Plasma elevation of uric acid levels observed in patients with DMII might reflect a compensatory mechanism to neutralize the oxidative stress associated with this disease. Thus, Berberis medicine, which has a hepato-renal drainage action and acting glycogenolysis, may have contributed to the significant reduction of the mean uric acid levels observed in the test group 6 and 12 months after NSPT and homeopathic treatment.

CRP is a nonspecific inflammatory marker (24). Its levels may increase by inflammatory conditions and/or chronic infections such as CP, obesity and DMII (24). In the present study, there was a significant reduction in CRP levels after periodontal treatment in both groups, but without significance between TG and CG. The reduction in CRP levels was observed after 6 months of periodontal treatment in patients with $\mathrm{CP}(25)$. Since the circulating CRP level is induced not only by the $\mathrm{CP}$, but also for other systemic conditions such as hyperglycemia and obesity (16), it is possible that the modest decrease observed in this study, have been influenced by these conditions.

A limitation of randomized clinical trials is that it may often not be repeated in clinical practice. In addition, if the study sample is highly selected, it may not represent the general population - in this case, generalization may be compromised. The specialized study environment of a randomized study may result in internally valid conclusions, but the results may not be generalized for patients with the same condition outside the study.

In the present study, the levels of TC, LDL TRIG decreased after 6 and 12 months while there was an increase in $\mathrm{HDL}$, in both groups. These data are consistent with the conclusion of studies that demonstrate the change in these parameters in patients with $\mathrm{DM} \mathrm{II}$ and $\mathrm{CP}$ after periodontal treatment $(15,17)$.

In conclusion, test and control groups presented significant improvements of their periodontal and laboratorial conditions, after 6 and 12 months of periodontal treatment. However, the results of the present study suggest that homeopathy as supplement of NSPT may further improve health condition, including glycemic control, in DMII patients with CP.

\section{Resumo}

Periodontite crônica (CP) e Diabetes mellitus tipo 2 (DMII) são doenças crônicas normalmente tratadas por práticas convencionais. Por outro Iado, a homeopatia pode colaborar no tratamento de diferentes doenças. 0 objetivo do presente estudo foi avaliar os efeito da homeopatia como adjunto a terapia periodontal não cirúrgica (NSPT) em indivíduos com CP e DMII. Oitenta individuos com CP e DMII de ambos os sexos com idade entre 32 e 70 anos, participaram desse estudo clínico randomizado, placebo controlado, duplo cego. Os pacientes foram divididos em 2 grupos: grupo controle (CG) e grupo teste (TG), e ambos receberam NSPT. TG também recebeu terapia homeopática, incluindo Berberis, Mercurius solubilis/ Belladonna/Hepar sulphur and Pyrogenium, enquanto o CG recebeu placebo. Exames clínicos e laboratoriais foram avaliados no baseline e 1, 6 e 12 meses após o tratamento. Ambos grupos mostraram melhoras significantes através do estudo para a maioria dos parâmetros avaliados. TG apresentou um ganho significativo nos níveis clínicos de inserção aos 1 e 12 meses, quando comparado ao grupo controle. Valores médios de glicemia e hemoglobina glicada reduziram significativamente em ambos grupos aos 6 e 12 meses. Entretanto, houve uma redução adicional desses parâmetros no TG, quando comparado ao CG. Concluindo, homeopatia como suplemento a NSPT pode promover as condições de saúde, incluindo o controle glicêmico, em pacientes com DMII e CP.

\section{References}

1. Sanz M, van Winkelhoff AJ. Periodontal infections: understanding the complexity - Consensus of the Seventh European Workshop on Periodontology. J Clin Periodontol 2011:38:3-6.

2. Petersen $P E$, Ogawa $H$. Strengthening the prevention of periodontal disease: the WHO approach. J Periodontol 2005;76:2187-2193.

3. Mealey BL, Ocampo GL. Diabetes mellitus and periodontal disease. Periodontol 2000 2007;44:127-153.

4. Chen L, Magliano DJ, Zimmet PZ. The worldwide epidemiology of type 2 diabetes mellitus-present and future perspectives. Nature Reviews Endocrinology 2012;8,228-236.

5. Demmer RT, Desvarieux M, Holtfreter B, Jacobs DR Jr, Wallaschofski $H$, Nauck $M$, et al. Periodontal status and A1C change: longitudinal results from the study of health in Pomerania (SHIP). Diabetes Care 2010;33:1037-1043.

6. Nassar H, Kantarci A, van Dyke TE. Diabetic periodontitis: a model for activated innate immunity and impaired resolution of inflammation. Periodontol 2000 2007;43:233-244.

7. Ide R, Hoshuyama T, Wilson D, Takahashi K, Higashi T. Periodontal disease and incident diabetes: a seven-year study. J Dent Res 2011;90:41-46.

8. Mourão LC, Cataldo DM, Moutinho H, Fischer RG, Canabarro A. Additional effects of homeopathy on chronic periodontitis: a 1-year 
follow-up randomized clinical trial. Complement Ther Clin Pract 2014;20:141-146.

9. Srivastava P. Periodontal diseases and homeopathy. Homeopathic J 2012;5:1-3.

10. Tupe RS, Kulkarni A, Adeshara K, Shaikh S, Shah N, Jadhav A. Syzygium jambolanum and Cephalandra indica homeopathic preparations inhibit albumin glycation and protect erythrocytes: an in vitro study. Homeopathy 2015;104:197-204.

11. Sampath $S$, Narasimhan A, Chinta R, Nair KR, Khurana A, Nayak D, et al. Effect of homeopathic preparations of Syzygium jambolanum and Cephalandra indica on gastrocnemius muscle of high fat and high fructose-induced type-2 diabetic rats. Homeopathy 2013;102:160-171.

12. Mathie RT, Lloyd SM, Legg LA, Clausen J, Moss S, Davidson JR, et al. Randomised placebo-controlled trials of individualised homeopathic treatment: systematic review and meta-analysis. Syst Rev 2014;6:142.

13. Tonetti MS, Claffey N, European Workshop in Periodontology group C. Advances in the progression of periodontitis and proposal of definitions of a periodontitis case and disease progression for use in risk factor research. J Clin Periodontol 2005;32:210-213.

14. Abd El-Wahab, $A E$, Ghareeb $D A L$, Sarhan $E E$, Abu-Serie MM, El Demellawy M.A. In vitro biological assessment of Berberis vulgaris and its active constituent, berberine: antioxidants, antiacetylcholinesterase, anti-diabetic and anticancer effects BMC Compl Altern Med 2013;13:218.

15. Llambés F, Silvestre FJ, Hernández-Mijares A, Guiha R, Caffesse R. Effect of non-surgical periodontal treatment with or without doxycycline on the periodontium of type 1 diabetic patients. J Clin Periodontol 2005;32:915-920.

16. O'Connell PA, Foss MC, Uyemura AS, Suaid FA, Trevisan GL, Grisi MFM, et al. Effects of periodontal therapy on glycemic control and inflamatory markers. J. Periodontol 2008;4:774-783.
17. Lin SJ, Tu YK, Tsai SC, Lai SM, Lu HK. Non-surgical periodontal therapy with and without subgingival minocycline administration in patients with poorly controlled type II diabetes: a randomized controlled clinical trial. Clin Oral Investig 2012;16:599-609.

18. Lakschevitz F, Aboodi G, Tenenbaum H, Glogauer M. Diabetes and periodontal diseases: interplay and links. Curr Diabetes Rev 2011;7:433439.

19. Preshaw PM, Bissett SM. Periodontitis: oral complication of diabetes. Endocrinol Metab Clin North Am 2013;42:849-867.

20. Valentaviciene G, Paipaliene P, Nedzelskiene I, Zilinskas J, Anuseviciene OV. The relationship between blood serum lipids and periodontal condition. Stom Baltic Dental Max J 2005;8:96-100.

21. Jyothilakshmi V, Thellamudhu G, Kumar A, Khurana A, Nayak D, Kalaiselvi P. Preliminary investigation on ultra high diluted $B$. vulgaris in experimental urolithiasis. Homeopathy 2013;102:172-178.

22. Grassi D, Ferri L, Desideri G, Di Giosia P, Cheli P, Del Pinto R, et al.. Chronic hyperuricemia, uric acid deposit and cardiovascular risk. Curr Pharm Des 2013;19:2432-2438.

23. Wang J, Tan GJ, Han LN, Bai YY, He M, Liu HB. Novel biomarkers for cardiovascular risk prediction. J Geriatr Cardiol 2017;14:135-150.

24. Paraskevas S, Huizinga JD, Loos BG. A systematic review and metaanalyses on $\mathrm{C}$-reactive protein in relation to periodontitis. J Clin Periodontol 2008;35:277-290.

25. Caúla AL, Lira-Junior R, Tinoco EM, Fischer RG. The effect of periodontal therapy on cardiovascular risk markers: a 6-month randomized clinical trial. J Clin Periodontol 2014;41: 875-882.

Received February 9, 2018 Accepted July 24, 2018 